\title{
EVALUATION OF USING DIETARY PHYTOGENICS, AS GROWTH PROMOTERS, ON BROILER PERFORMANCE, UNDER NORMAL AND SUBNORMAL TEMPERATURE CONDITIONS
}

\author{
H.B. Gharib \\ Department of Animal Production, Faculty of Agriculture, Cairo University, Giza, Egypt \\ Email :( hassangharib2001@gmail.com)
}

\section{SUMMARY}

The present study was carried out to investigate the potential of dietary supplemental mixture of three phytogenics; carvacrol, cinnamaldehyde and capsicum oleoresin (Xtract ${ }^{T M}$ ) as growth promoter, under normal and subnormal temperature conditions. It was hypothesized that this mixture may alleviate the negative effects of cold stress on broilers performance and their immune response. Six hundred, one-day-old male broiler chicks, were subjected to one of two dietary treatments for 35 days: a basal diet as a control and the basal diet plus 100 ppm of Xtract ${ }^{T M}{ }^{\circledR}$. At 21days of age, half the birds in each dietary treatment were raised under one of two different ambient temperature treatments, the recommended normal temperature $\left(22-24^{\circ} \mathrm{C}\right)$ versus a subnormal temperature $\left(11-17^{\circ} \mathrm{C}\right)$, until 35 days of age. The results indicated that rearing broilers under subnormal temperature conditions, from 21 to 35 days of age, had significant negative effects on the production performance, carcass meat yield and immune response, as compared to those reared under normal temperature conditions. Under normal and subnormal temperature conditions, feed supplementation of 100 ppm Xtract ${ }^{T M}{ }^{\circledR}$ significantly increased final body weight, improved final feed conversion ratio, decreased total mortality rate, enhanced HI titers against Newcastle disease vaccine and consequently increased the profit potential of the birds, as compared to those not supplemented. Feed supplementation with Xtract ${ }^{T M}$ caused a significant increase in dressing percentage, breast meat, carcass meat as well as a significant decrease in abdominal fat. In addition, the Xtract ${ }^{T M}$ treated birds had significantly higher intestinal diameter and villus height than non treated ones. These results provide clear evidence to support the idea that the mixture of three phytogenics; carvacrol, cinnamaldehyde and capsicum oleoresin $\left(X t r a c t^{T M}\right.$ ) could be used as cost effective feed additive growth promoter in broilers up to 35 days of age, under normal as well as subnormal temperature conditions. Furthermore, Xtract ${ }^{T M}$ supplementation alleviated the negative effects of cold stress on production performance and immune response in broilers.

\section{Keywords: broilers, phytoogenics, productive performance, immune response}

\section{INTRODUCTION}

It has been well established that the usage of antibiotics, in animal diet, as growth promoters, is absolutely beneficial for the improvement of productive performance parameters and prevention of diseases (Karimi et al., 2010 and Puvaca et al., 2013). Nevertheless, because of the threats for human and animal health which come from resistant of pathogens to antibiotics and the accumulation of antibiotic residues in animal products and the environment (Stanacev et al., 2011), there is a global need to eliminate antibiotic growth promoters from animal diets. Earlier, antibiotic have been banned from animal and poultry diet by European Union since the year 2006. The demand for alternative products to antibiotics that can be used as prophylactic and growth promoting agents is very high. During the past several years, phytogenic compounds have attracted a lot of attention for their potential role as alternative to antibiotic growth promoters in animal nutrition (Puvaca et al., 2013).

The term "phytogenic compound" refers to the parts (e.g. seeds, fruits, roots, and leafs) of various aromatic herbs and spices (e.g. garlic, oregano, thyme, rosemary, coriander and cinnamon) as well as respective plant extracts in the form of essential oil (Windisch et al., 2008 and Stanacev et al., 2011). These compounds are also called phytonutrients or phytochemicals. Many beneficial properties of phytogenic compounds derive from their bioactive molecules (e.g. carvacrol, thymol, cineole, allicin, capsaicin and piperine) (Windisch et al., 2008).

The proposed mode of action of phytogenic compounds in poultry is attributed to their antimicrobial properties (Kollanoor-Johny et al., 2012, Renata et al., 2012 and Lee et al., 2013), antiviral (Burt, 2004), oxidative-resistant activity (Windisch et al., 2008), anti-inflammatory (Lee et al., 2009), enhancement of the immune system (Lillehoj et al., 2010 and Lee et al., 2013) and consequently, improvement in poultry performance. Besides efficacy, application of phytogenic feed additives to livestock also has to be safe to the animal, the consumer of the animal product, and the environment (Windisch et al., 2008).

Among these products, the mixture of three phytogenic compounds, namely carvacrol, cinnamaldehyde, and capsicum oleoresin, were reported as anti-bacterial and anti-fungal agents (Jamroz et al., 2005). Carvacrol is a component of numerous aromatic plants, such as Origanum vulgare, thyme, and wild bergamot (De Vincenzi et al., 2004). The anti-microbial functions of these plant extracts are associated with carvacrol, which inhibit Salmonella growth in chickens (Burt et al., 2005 and 2007). On the other hand, Lee et al. (2003) reported 
that dietary carvacrol lowered feed intake and weight gain but also lowered the feed-to-gain ratio. Cinnamaldehyde is a constituent of cinnamon and widely applied as flavoring. It has been proven to have strong anti-bacterial activity against Escherichia coli, Pseudomonas aeruginosa, Staphylococcus aureus, Staphylococcus epidermidis, and Salmonella sp. (Chang et al., 2001). Capsicum oleoresin, prepared by organic extraction of pepper fruits, contains anti-bacterial activity (Loizzo et al., 2008).

The results of the experiments that have been carried out to evaluate the response of broiler chicks to phytogenic compounds feed additives are inconclusive and not consistent and presented a scattered picture. Whereas some researchers have reported the full or partial effectiveness of phytogenic compounds in improving broiler performance (Jamroz et al., 2005, Burt et al., 2007 and Alali et al., 2013), others have reported no significant improvement (Hernandez et al., 2004, Lee et al., 2004a, Karimi et al., 2010 and KollanoorJohny et al., 2012). On the other hand, depressions in production performance due to phytogenic compounds feed additives were also reported (Cross et al., 2007). The broiler response to phytogenic compounds supplements is highly influenced by many factors such as environmental and sanitary conditions (Jamroz et al., 2005 and Hashemi and Davoodi, 2010).

Exposure of broiler chicks to temperatures, below the thermoneutral zone $\left(18\right.$ to $\left.24^{\circ} \mathrm{C}\right)$, after 3 weeks of age, has negative effects on the productive performance, meat yield, immune response, and mortality rate (Olanrewaju et al., 2010). Therefore, the present study was carried out to determine whether dietary supplemental mixture of carvacrol, cinnamaldehyde, and capsicum oleoresin (Xtract ${ }^{\mathrm{TM} \circledast}$ ) could have the potential as growth promoter as well as alleviation of the negative effects of cold stress on broilers performance. The parameters evaluated were production performance, carcass yield, profit potential and immune response of broilers.

\section{MATERIALS AND METHODS}

\section{Experimental design:}

Six hundred one-day-old, feather-sexed male broiler chicks (Arbor Acres Plus) were obtained from a local hatchery, in December 2012 and were raised for 35days. They were randomly distributed to one of two open sided rooms (A\&B). The rooms A and B had the same floor and windows areas and the same wind direction. Each room housed 300 chicks under two dietary treatments, each 150 chicks. Each treatment had 10 replicates of deep litter pens $(1 \times 1.5$ m) with 15 birds per replicate. The two dietary treatments were as follows: control group $=$ a basal diet and an $\mathrm{Xtract}^{\mathrm{TM} \circledast}$ group= basal diet $+\mathrm{Xtract}^{\mathrm{TM} \circledast}$ 6930, batch No. 57425 (produced by Pancosma, Switzerland), in a dosage according to the manufacturer's recommendations $(100 \mathrm{ppm})$. Xtract $^{\mathrm{TM} \circledast} 6930$ is a mixture of three plant extracts containing $5.4 \%$ (wt/wt) carvacrol $\left(\mathrm{C}_{10} \mathrm{H}_{14} \mathrm{O}\right.$; from oregano, Origanum spp.), $3.2 \% \quad$ (wt/wt) cinnamaldehyde $\left(\mathrm{C}_{9} \mathrm{H}_{8} \mathrm{O}\right.$, from cinnamon, Cinnamonum spp.) and $2.2 \%$ (wt/wt) capsicum oleoresin $\left(\mathrm{C}_{18} \mathrm{H}_{27} \mathrm{NO}_{3}\right.$ from Mexican pepper, Capsicum annuum) (Renata et al., 2012). This mixture was administered, in feed, via a premix on a vegetal carrier, from one-day-old until 35 days of age.

\section{Ambient temperature treatments:}

Standard brooding temperatures were maintained for all birds for the first 21 days of age. The temperature was set at $32^{\circ} \mathrm{C}$ on the first day, gradually reduced to $24^{\circ} \mathrm{C}$ at 21 days of age, when temperature treatments started. At 21 days of age, the birds were placed under two different temperature conditions treatments in rooms $\mathrm{A}$ and $\mathrm{B}$. In room A, the birds were raised under the recommended normal temperature (NT group), 22 to $24^{\circ} \mathrm{C}$, (Daneshyar et al., 2009) by using slight heating of the room. In room B, the birds were reared under subnormal temperature (SNT group), $11-17^{\circ} \mathrm{C}$, by exposure to the ambient temperatures and winds in January, without heating, (January being the coldest month in Egypt's subtropical climate). Due to the cold climate, the minimum daily temperature recorded in room $\mathrm{B}$ varied from 10 to $12^{\circ} \mathrm{C}$ with a mean of $11^{\circ} \mathrm{C}$. The maximum daily temperature ranged between 15 and $19^{\circ} \mathrm{C}$ with a mean of $17^{\circ} \mathrm{C}$. In the two rooms, the temperature and humidity were recorded with thermohygrometers. The humidity ranged from 50 to $60 \%$, from 21 to 35 days of age.

\section{General management:}

The composition of the diets and their calculated analysis are shown in Table 1 . The commercial diets used were formulated to meet the nutrient requirements of the broiler chicks during starter, grower and finisher periods according to the National Research Council (NRC, 1994). Broilers were fed, ad libitum, a corn-soybean meal starter diet (23\% crude protein and $3000 \mathrm{k} \mathrm{cal} \mathrm{ME} / \mathrm{kg}$ diet) during the first 2 weeks of age, a grower diet $(21 \%$ crude protein and $3100 \mathrm{kcal} \mathrm{ME} / \mathrm{kg} \mathrm{diet)} \mathrm{from} \mathrm{2-4} \mathrm{weeks} \mathrm{of} \mathrm{age,} \mathrm{and} \mathrm{a}$ finisher diet (19\% crude protein and $3200 \mathrm{kcal}$ $\mathrm{ME} / \mathrm{kg}$ diet) during the $5^{\text {th }}$ week of age. Starter feed was provided as crumbles, and subsequent feeds were provided as pellets. Semduramicin was added to the rations at a concentration of $25 \mathrm{ppm}$ as a coccidiostat. Daily fluorescent illumination was applied for $23 \mathrm{~h}$ with $1 \mathrm{~h}$ of dark throughout the experimental period. Rooms were bedded with wood shavings and each replicate was equipped with 1 bell-shape drinker and 1 round tank feeder. All experimental birds were vaccinated against different diseases according to the vaccination programs adopted in most Egyptian chicken broiler farms (Elmenawey and Gharib, 2013). The vaccination program included vaccination against Newcastle disease (ND) using Hitchner B1 and La Sota strain live vaccines (via drinking water) at 7 and 18 days of age, respectively. 
Table 1. Composition of the 3-phase diets ( $\mathrm{g} / \mathrm{kg}$ as fed) used and their calculated analysis

\begin{tabular}{lccc}
\hline Ingredients & Starter (0-14 d) & Grower (15-28 d) & Finisher (29-35 d) \\
\hline Yellow corn & 524.5 & 544.2 & 628.5 \\
Soybean meal 44\% & 332.4 & 299.1 & 221.1 \\
Corn gluten meal 60\% & 70 & 70 & 66.5 \\
Soya oil & 30 & 43.8 & 40 \\
Di-calcium phosphate & 18 & 18 & 18 \\
Lime stone & 13 & 13 & 13 \\
D.L. Methionine & 2.2 & 2.1 & 2.3 \\
Lysine hydrochloride & 2.9 & 2.8 & 3.6 \\
Sodium chloride & 4 & 4 & 4 \\
Premix* & 3 & 3 & 3 \\
Calculated analysis: & & & 19.0 \\
Crude protein \% & 23.0 & 21.0 & 3200 \\
Metabolizable energy (kcal/kg) & 3000 & 3100 & \\
\hline
\end{tabular}

*Each gram of the premix contained: vitamin A (trans-retinyl acetate), 9,000 IU; vitamin D3 (cholecalciferol), 2,600 IU; vitamin $\mathrm{E}$ (dl- $\alpha$-tocopheryl acetate), $16 \mathrm{mg}$; vitamin $\mathrm{B} 1,1.6 \mathrm{mg}$; vitamin $\mathrm{B} 2,6.5 \mathrm{mg}$; vitamin $\mathrm{B} 6,2.2 \mathrm{mg}$; vitamin B12 (cyanocobalamin), $0.015 \mathrm{mg}$; vitamin K3, 2.5mg; choline (choline chloride), $300 \mathrm{mg}$; nicotinic acid, $30 \mathrm{mg}$; pantothenic acid (d-calcium pantothenate), $10 \mathrm{mg}$; folic acid, $0.6 \mathrm{mg}$; d-biotin, $0.07 \mathrm{mg}$; manganese $(\mathrm{MnO}), 70 \mathrm{mg}$; zinc $(\mathrm{ZnO}), 60 \mathrm{mg}$; iron $\left(\mathrm{FeSO}_{4} \mathrm{H}_{2} \mathrm{O}\right), 40 \mathrm{mg}$; copper $\left(\mathrm{CuSO}_{4} 5 \mathrm{H}_{2} \mathrm{O}\right), 7 \mathrm{mg}$; iodine $\left[\mathrm{Ca}\left(\mathrm{IO}_{3}\right)_{2}\right], 0.7 \mathrm{mg}$; selenium $\left(\mathrm{Na}_{2} \mathrm{SeO}_{3}\right), 0.3 \mathrm{mg}$.

\section{Measured parameters: \\ Production performance:}

Individual body weights were obtained on d 1, 21, and 35 of age. Total feed consumption (FC), from 0 5 weeks of age in each replicate was calculated per bird (g/bird). The feed conversion ratio (FCR) was determined as the FC per body weight gain $(\mathrm{g} / \mathrm{g})$ for each replicate. Weight of the dead birds was used to adjust feed conversion. Mortality was recorded daily. Dead birds were subjected to postmortem examinations and those with accumulation of abdominal or pericardial fluids were diagnosed as ascites mortality (Ozkan et al., 2010). According to Timmerman et al. (2006), an index of productivity, so-called production number, which equals (Kilograms of growth per day * (100 - mortality \%)) $* 100$ / Feed conversion ratio was calculated for each replicate, at the end of the experimental period.

\section{Carcass yield:}

At 35 days of age, 3 birds from each replicate were randomly chosen, fasted for 8 hours then weighed and slaughtered. After blood removal, they were defeathered, processed, and eviscerated. Determinations of carcass yield (dressing \%, breast meat $\%$, thigh with drumstick meat $\%$, carcass meat $\%$, abdominal fat $\%$, and giblets (liver + heart + gizzard) \%) were determined, as a percent of the fasting live body weights.

\section{Intestinal length and diameter:}

At 35 days of age, the small intestine of 3 birds, from each replicate (the segment between gizzard and ileocecal junction), was removed. It's length and diameter (in the middle of ileum) were measured.

\section{Ileal mucosa:}

At the end of the experiment, one bird from each replicate was chosen at random and sacrificed. Their small intestine was collected and immediately immersed in $10 \%$ buffered formalin. After fixation, 2 $\mathrm{cm}$ samples were taken from the middle of ileum. The ileum was considered from the Meckel's diverticulum to ileocecal junction (Samanya and Yamauchi, 2002). Routine histological laboratory methods were done (Zhang et al., 2005). The slides were stained with hematoxylineosin. Histological indices were measured using digital photography and light microscopy. The villus height $(\mu \mathrm{m})$ was measured from the apical to the basal region, which corresponded to the superior portion of the crypts. Crypts depth $(\mu \mathrm{m})$ was measured from the base until the region of transition between the crypt and the villus.

\section{Relative weights of spleen, thymus and bursa of Fabricius:}

At 35 days of age, determination of the relative spleen, thymus and bursa of fabricius weights, as a percent of the fasting live body weights, were performed on 3 birds from each replicate.

\section{Humoral Anti-ND vaccine antibody titers:}

For determination of the effect of the temperature conditions and $\mathrm{Xtract}^{\mathrm{TM} \circledast}$ supplementation on humoral immunity; blood samples were collected from wing veins of 3 birds from each replicate, chosen at random, at 35 days of age. Serum samples were subjected to $\mathrm{HI}$ test for determining antibody titers against Newcastle disease (ND) vaccine as described by Swayne et al. (1998).

\section{Profit potential:}

Profit potential was calculated as the income over cost, per each replicate, under normal or subnormal temperature conditions. The income was calculated as live body weight at 35 days of age, which was based on a price of 13 Egyptian pounds (LE) per $\mathrm{kg}$. The cost included chick, feed and Xtract ${ }^{\mathrm{TM} \circledast}$ costs per chick. The chick price was LE 3.0; the mortality rate was used to adjust the chick cost. Feed cost was calculated from the actual feed cost incurred during the course of the experiment. The price for one ton ration was LE 4300 for starter diet, LE 4200 for grower diet and LE 4100 for finisher diet. The price for one $\mathrm{kg}$ of $\mathrm{Xtract}^{\mathrm{TM} \circledast}$ was LE 200. 
Statistical analyses:

Two-way analysis of variance was done using the SAS GLM software procedure (SAS Institute, 1999). The main factors were temperature conditions and Xtract $^{\mathrm{TM} \circledast}$ supplementation. Percentage data were subjected to arc-sine transformation prior to analysis. Mean values were compared using Duncan's Multiple Range Test (Duncan, 1955) when significant differences existed. Significance was set at $\mathrm{P}<0.05$.

\section{RESULTS}

\section{Production performance:}

Results of the effects of temperature conditions and feed supplementation with mixture of carvacrol, cinnamaldehyde and capsicum oleoresin (Xtract ${ }^{\mathrm{TM} \otimes}$ ) on production performance in broilers are shown in Table 2. Birds grown under subnormal temperature
(SNT) conditions had significantly lower body weights, at 35 days of age, than those grown under normal temperature (NT) conditions. The results revealed that, in general, there were significant increases in final body weight, at 35 days of age, for the birds that received the Xtract ${ }^{\mathrm{TM}}{ }^{\circledR}(100 \mathrm{mg} / \mathrm{kg}$ diet $)$ over the non treated group. The data of body weight, at 35 days of age, indicated a significant interaction between the temperature conditions and $\mathrm{Xtract}^{\mathrm{TM} \otimes}$ supplementation. Birds reared under NT and consumed diet with Xtract ${ }^{\mathrm{TM}}$, had significantly the heaviest body weights. However, birds that were reared under SNT and consumed the basal diet had significantly the lowest body weights. The other two treatment groups (birds under NT with no Xtract ${ }^{\mathrm{TM}}$ and birds under SNT plus $\mathrm{Xtract}^{\mathrm{TM}}$ ) body weights were intermediate with no significant differences between them.

Table 2. Effects of temperature conditions and feed supplementation with $\mathrm{Xtract}^{\mathrm{TM}}{ }^{\circledR}$ on production performance of broilers

\begin{tabular}{|c|c|c|c|c|c|c|c|}
\hline \multirow[b]{2}{*}{ Main effects } & \multicolumn{3}{|c|}{ Body weight (g) } & \multirow{2}{*}{$\begin{array}{l}\text { Total } \\
\text { FC }^{2} \\
\text { (g/bird) }\end{array}$} & \multirow{2}{*}{$\mathbf{F C R}^{3}$} & \multirow{2}{*}{$\begin{array}{c}\text { Total } \\
\text { mortality } \\
\%\end{array}$} & \multirow{2}{*}{$\begin{array}{c}\text { Production } \\
\text { number }\end{array}$} \\
\hline & $\begin{array}{l}\text { One } \\
\text { day }\end{array}$ & $\begin{array}{c}21 \\
\text { days }\end{array}$ & $\begin{array}{c}35 \\
\text { days }\end{array}$ & & & & \\
\hline Temperature conditions $(\mathrm{T}) *$ & & & & & & & \\
\hline $\begin{array}{l}\text { Normal temperature (NT) } \\
\text { Subnormal temperature (SNT) }\end{array}$ & $\begin{array}{l}46.4 \\
46.5\end{array}$ & $\begin{array}{l}834.9 \\
837.1\end{array}$ & $\begin{array}{l}2120^{\mathrm{a}} \\
2046^{\mathrm{b}}\end{array}$ & $\begin{array}{l}3382 \\
3413\end{array}$ & $\begin{array}{l}1.595^{b} \\
1.660^{a}\end{array}$ & $\begin{array}{l}3.42^{\mathrm{b}} \\
4.97^{\mathrm{a}}\end{array}$ & $\begin{array}{l}359.1^{\mathrm{a}} \\
327.6^{\mathrm{b}}\end{array}$ \\
\hline $\begin{array}{c}\text { SEM }^{1} \\
\text { Probability } \\
\text { Xtract }^{\mathrm{TM} \circledast} \text { supplementation }(\mathrm{X}) \\
\end{array}$ & $\begin{array}{l}0.2 \\
\text { NS }\end{array}$ & $\begin{array}{l}8.7 \\
\text { NS }\end{array}$ & $\begin{array}{c}14 \\
<0.001\end{array}$ & $\begin{array}{c}34 \\
\text { NS }\end{array}$ & $\begin{array}{l}0.011 \\
<0.01\end{array}$ & $\begin{array}{c}0.34 \\
<0.001\end{array}$ & $\begin{aligned} & 7.5 \\
< & 0.01\end{aligned}$ \\
\hline $\begin{array}{c}\text { No Xtract }{ }^{\mathrm{TM}}{ }^{\circledR} \\
\text { Xtract }^{\mathrm{TM}} \text { group (NXS) } \\
\text { group (XS) }\end{array}$ & $\begin{array}{l}46.5 \\
46.4\end{array}$ & $\begin{array}{l}834.5 \\
837.6\end{array}$ & $\begin{array}{l}2033^{b} \\
2133^{a}\end{array}$ & $\begin{array}{l}3378 \\
3417\end{array}$ & $\begin{array}{l}1.658^{\mathrm{a}} \\
1.597^{\mathrm{b}}\end{array}$ & $\begin{array}{l}4.57^{\mathrm{a}} \\
3.82^{\mathrm{b}}\end{array}$ & $\begin{array}{l}327.0^{\mathrm{b}} \\
359.7^{\mathrm{a}}\end{array}$ \\
\hline $\begin{array}{c}\text { SEM } \\
\text { Probability } \\
\mathrm{T} * \mathrm{X} \text { Interaction } \\
\end{array}$ & $\begin{array}{l}0.3 \\
\text { NS }\end{array}$ & $\begin{array}{l}8.4 \\
\mathrm{NS}\end{array}$ & $\begin{array}{c}15 \\
<0.001\end{array}$ & $\begin{array}{l}35 \\
\text { NS }\end{array}$ & $\begin{array}{l}0.012 \\
<0.01\end{array}$ & $\begin{array}{c}0.23 \\
<0.01\end{array}$ & $\begin{aligned} & 7.8 \\
< & 0.01\end{aligned}$ \\
\hline $\begin{array}{l}\mathrm{NT} * \mathrm{NXS} \\
\mathrm{NT} * \mathrm{XS} \\
\mathrm{SNT} * \mathrm{NXS} \\
\mathrm{SNT} * \mathrm{XS}\end{array}$ & $\begin{array}{l}46.5 \\
46.3 \\
46.6 \\
46.5\end{array}$ & $\begin{array}{l}835.2 \\
834.6 \\
833.7 \\
840.5\end{array}$ & $\begin{array}{l}2064^{\mathrm{b}} \\
2175^{\mathrm{a}} \\
2001^{\mathrm{c}} \\
2090^{\mathrm{b}}\end{array}$ & $\begin{array}{l}3360 \\
3404 \\
3395 \\
3430\end{array}$ & $\begin{array}{l}1.627^{\mathrm{b}} \\
1.563^{\mathrm{c}} \\
1.688^{\mathrm{a}} \\
1.631^{\mathrm{b}}\end{array}$ & $\begin{array}{l}3.83^{\mathrm{c}} \\
3.00^{\mathrm{d}} \\
5.31^{\mathrm{a}} \\
4.63^{\mathrm{b}}\end{array}$ & $\begin{array}{l}340.7^{\mathrm{b}} \\
377.5^{\mathrm{a}} \\
313.3^{\mathrm{c}} \\
341.9^{\mathrm{b}}\end{array}$ \\
\hline $\begin{array}{c}\text { SEM } \\
\text { Probability }\end{array}$ & $\begin{array}{l}0.2 \\
\text { NS }\end{array}$ & $\begin{array}{l}7.6 \\
\text { NS }\end{array}$ & $\begin{array}{c}14 \\
<0.001\end{array}$ & $\begin{array}{c}33 \\
\text { NS }\end{array}$ & $\begin{array}{l}0.010 \\
<0.01\end{array}$ & $\begin{array}{c}0.25 \\
<0.001\end{array}$ & $\begin{array}{c}7.1 \\
<0.01\end{array}$ \\
\hline
\end{tabular}

\footnotetext{
${ }^{\mathrm{a}, \mathrm{d}}$ Means, within a column and effect, followed by different superscripts differ significantly.

${ }^{*}$ Temperature treatment started at 21 days of age. $\quad{ }^{1} \mathrm{SEM}=$ Stander error of the mean.

${ }^{2} \mathrm{FC}=$ Feed consumption

${ }^{3} \mathrm{FCR}=\mathrm{FC}(\mathrm{g}) /$ weight gain $(\mathrm{g})$
}

Data of total feed consumption (Table 2) indicated that there were no significant effects due to either temperature conditions or Xtract ${ }^{\mathrm{TM} \circledast}$ supplementation, or the interaction between them. Rearing the birds under SNT conditions resulted in significantly higher final feed conversion ratio, as compared to NT conditions (Table 2). The addition of Xtract ${ }^{\mathrm{TM}}$ significantly improved the final feed conversion ratio. There was a significant interaction between the two treatments on the final feed conversion ratios. Birds that were reared under SNT conditions and consumed the basal diet had significantly the worst feed conversion. Whereas, birds reared under NT conditions and consumed the $\mathrm{Xtract}^{\mathrm{TM} \circledast}$ diet had the best feed conversion. The 
other two treatment groups were intermediate with no significant differences between them.

Regardless of the two treatments, no mortality due to ascites was observed (Table 2). Significantly higher mortality rate was present in the SNT group, compared with NT birds. The supplementation of Xtract ${ }^{\mathrm{TM}}{ }^{\circledR}$ significantly decreased the total mortality percentage. Our data indicated a significant interaction between the temperature conditions and $\mathrm{Xtract}^{\mathrm{TM} \otimes}$ supplementation on the total mortality percentage. Birds that were reared under SNT conditions and fed the basal diet had the highest total mortality percentage. However, the lowest total mortality percentage was observed in the NT plus Xtract $^{\mathrm{TM} \circledast}$ group. The other two experimental groups were intermediate, with the NT plus basal diet group had, significantly, lower total mortality than the SNT plus Xtract ${ }^{\mathrm{TM} \otimes}$ group.

The SNT conditions resulted in a significant decrease in the production number as compared to NT conditions (Table 2). However, the Xtract ${ }^{\mathrm{TM} \circledast}$ group had significantly higher production number than the not supplemented group. Significant interaction between the two treatments on the production number was also observed. Birds in the NT plus Xtract ${ }^{\mathrm{TM}}$ group had the highest production number. However, the lowest production number was that of the SNT plus basal diet group.
The other two treatment groups were intermediate with no significant differences between them.

\section{Carcass yield:}

Data of carcass yield, expressed as percentages of the live body weight, are presented in Table 3. Birds subjected to the SNT conditions had significantly lower breast and carcass meat yields, and abdominal fat deposition compared to the NT conditions group. There were no significant temperature conditions effects on dressing, thigh with drumstick meat or giblets percentages. The effect of feed supplementation with $\mathrm{Xtract}^{\mathrm{TM} \circledast}$ on carcass yield resulted in significant increases in dressing $\%$, and breast and carcass meat percentages as well as a significant decrease in abdominal fat $\%$. There were significant interaction between the two treatments on dressing percentage, breast and carcass meat, and abdominal fat percentages. Under normal or subnormal temperature conditions, birds that consumed $\mathrm{Xtract}^{\mathrm{TM} \circledast}$ feed had significantly higher percentages of dressing, breast meat and carcass meat, as compared to those received the basal diet. Birds in the NT plus Xtract ${ }^{\mathrm{TM}}$ group had the lowest abdominal fat percentage, compared to the rest of the groups.

Table 3. Effects of temperature conditions and feed supplementation with $\mathrm{Xtract}^{\mathrm{TM}}{ }^{\circledR}$ on carcass yield $^{1}$ of $^{-}$ broilers, at 35 days of age

\begin{tabular}{|c|c|c|c|c|c|c|}
\hline Main effects & $\begin{array}{c}\text { Dressing } \\
\%\end{array}$ & $\begin{array}{c}\text { Breast } \\
\text { meat } \\
\%\end{array}$ & $\begin{array}{c}\text { Thigh }+ \\
\text { drumstick } \\
\text { meat } \%\end{array}$ & $\begin{array}{l}\text { Carcass } \\
\text { meat } \%\end{array}$ & $\begin{array}{l}\text { Abdominal } \\
\text { fat } \%\end{array}$ & $\begin{array}{l}\text { Giblets } \\
\%\end{array}$ \\
\hline \multicolumn{7}{|l|}{ Temperature conditions $(\mathrm{T})$} \\
\hline $\begin{array}{l}\text { Normal temperature }(\mathrm{NT}) \\
\text { Subnormal temperature (SNT) }\end{array}$ & $\begin{array}{l}69.08 \\
69.00\end{array}$ & $\begin{array}{l}20.12^{\mathrm{a}} \\
18.72^{\mathrm{b}}\end{array}$ & $\begin{array}{l}15.39 \\
15.41\end{array}$ & $\begin{array}{l}35.50^{\mathrm{a}} \\
34.13^{\mathrm{b}}\end{array}$ & $\begin{array}{l}1.32^{\mathrm{a}} \\
1.11^{\mathrm{b}}\end{array}$ & $\begin{array}{l}4.60 \\
4.69\end{array}$ \\
\hline $\begin{array}{c}\text { SEM }^{2} \\
\text { Probability } \\
\text { Xtract }^{\mathrm{TM} \circledast} \text { supplementation }(\mathrm{X}) \\
\end{array}$ & $\begin{array}{l}0.33 \\
\mathrm{NS}\end{array}$ & $\begin{array}{c}0.31 \\
<0.01\end{array}$ & $\begin{array}{l}0.35 \\
\mathrm{NS}\end{array}$ & $\begin{array}{c}0.30 \\
<0.05\end{array}$ & $\begin{array}{c}0.07 \\
<0.01\end{array}$ & $\begin{array}{l}0.10 \\
\mathrm{NS}\end{array}$ \\
\hline $\begin{array}{c}\text { No Xtract } \\
\text { Xtract }^{\mathrm{TM}}{ }^{\mathrm{T}} \text { group } \\
\text { group (NS) }\end{array}$ & $\begin{array}{l}68.15^{\mathrm{b}} \\
69.93^{\mathrm{a}}\end{array}$ & $\begin{array}{l}18.76^{\mathrm{b}} \\
20.08^{\mathrm{a}}\end{array}$ & $\begin{array}{l}15.28 \\
15.51\end{array}$ & $\begin{array}{l}34.04^{\mathrm{b}} \\
35.59^{\mathrm{a}}\end{array}$ & $\begin{array}{l}1.31^{\mathrm{a}} \\
1.12^{\mathrm{b}}\end{array}$ & $\begin{array}{l}4.65 \\
4.64\end{array}$ \\
\hline $\begin{array}{c}\text { SEM } \\
\text { Probability } \\
\mathrm{T} * \mathrm{X} \text { Interaction } \\
\end{array}$ & $\begin{array}{l}0.28 \\
<0.05\end{array}$ & $\begin{array}{c}0.41 \\
<0.01\end{array}$ & $\begin{array}{l}0.29 \\
\mathrm{NS}\end{array}$ & $\begin{array}{c}0.32 \\
<0.05\end{array}$ & $\begin{array}{c}0.06 \\
<0.01\end{array}$ & $\begin{array}{l}0.11 \\
\mathrm{NS}\end{array}$ \\
\hline $\begin{array}{l}\text { NT } * \text { NXS } \\
\text { NT *XS } \\
\text { SNT } * \text { NXS } \\
\text { SNT } * \text { XS }\end{array}$ & $\begin{array}{l}68.19^{\mathrm{b}} \\
69.96^{\mathrm{a}} \\
68.11^{\mathrm{b}} \\
69.89^{\mathrm{a}}\end{array}$ & $\begin{array}{l}19.40^{b} \\
20.84^{\mathrm{a}} \\
18.12^{\mathrm{c}} \\
19.31^{\mathrm{b}}\end{array}$ & $\begin{array}{l}15.25 \\
15.52 \\
15.31 \\
15.49\end{array}$ & $\begin{array}{l}34.65^{b} \\
36.35^{a} \\
33.43^{c} \\
34.80^{b}\end{array}$ & $\begin{array}{l}1.45^{\mathrm{a}} \\
1.18^{\mathrm{b}} \\
1.15^{\mathrm{b}} \\
1.06^{\mathrm{b}}\end{array}$ & $\begin{array}{l}4.58 \\
4.62 \\
4.72 \\
4.66\end{array}$ \\
\hline $\begin{array}{c}\text { SEM } \\
\text { Probability }\end{array}$ & $\begin{array}{c}0.28 \\
<0.05\end{array}$ & $\begin{array}{c}0.39 \\
<0.05\end{array}$ & $\begin{array}{l}0.25 \\
\mathrm{NS}\end{array}$ & $\begin{array}{c}0.35 \\
<0.05\end{array}$ & $\begin{array}{c}0.07 \\
<0.05\end{array}$ & $\begin{array}{l}0.08 \\
\mathrm{NS}\end{array}$ \\
\hline
\end{tabular}

\footnotetext{
${ }^{\mathrm{a}, \mathrm{c}}$ Means, within a column and effect, followed by different superscripts differ significantly.

1 carcass yield expressed as percentages of the fasting live body weight.

${ }^{2} \mathrm{SEM}=$ Stander error of the mean.
} 
Intestinal length and diameter:

The results presented in Table 4 indicated that the temperature conditions had no significant effects on intestinal length or diameter. However, the Xtract ${ }^{\mathrm{TM} \circledast}$ treated birds had significantly wider intestinal diameter, as compared to the not treated group. No significant differences were observed in the intestinal length due to the Xtract ${ }^{\mathrm{TM}}$ supplementation.
There was significant interaction between temperature and $\mathrm{Xtract}^{\mathrm{TM} \circledast}$ treatments on the intestinal diameter. Under normal or subnormal temperature conditions, birds consumed Xtract ${ }^{\mathrm{TM} \circledast}$ feed had significantly wider intestinal diameter, as compared to the no Xtract ${ }^{\mathrm{TM}}{ }^{\circledR}$ fed group. Within the Xtract $^{\mathrm{TM} \circledast}$ treatment, no significant temperature effects on the intestinal diameter were observed.

Table 4. Effects of temperature conditions and feed supplementation with Xtract ${ }^{\text {TM® }}$ on intestinal morphology and ileal mucosa morphology of broilers, at 35 days of age

\begin{tabular}{|c|c|c|c|c|c|}
\hline \multirow[b]{2}{*}{ Main effects } & \multicolumn{2}{|c|}{ Intestinal morphology } & \multicolumn{3}{|c|}{ Ileal mucosa morphology } \\
\hline & $\begin{array}{l}\text { Intestine } \\
\text { length } \\
(\mathrm{cm})\end{array}$ & $\begin{array}{l}\text { Intestine } \\
\text { diameter } \\
(\mathrm{cm})\end{array}$ & $\begin{array}{l}\text { Villus } \\
\text { height } \\
(\mu \mathrm{m})\end{array}$ & $\begin{array}{l}\text { Crypt } \\
\text { depth } \\
(\mu \mathrm{m})\end{array}$ & $\begin{array}{l}\text { Villus height } \\
\text { / } \\
\text { Crypt depth } \\
\text { ratio }\end{array}$ \\
\hline \multicolumn{6}{|l|}{ Temperature conditions $(\mathrm{T})$} \\
\hline Normal temperature (NT) & 188.9 & 0.982 & 362 & 118 & 3.09 \\
\hline Subnormal temperature (SNT) & 183.0 & 0.977 & 344 & 123 & 2.82 \\
\hline SEM $^{1}$ & 7.2 & 0.092 & 22 & 12 & 0.25 \\
\hline Probability & NS & NS & NS & NS & $\mathrm{NS}$ \\
\hline \multicolumn{6}{|l|}{$\underline{\text { Xtract }^{\mathrm{TM} \circledast} \text { supplementation }(\mathrm{X})}$} \\
\hline No Xtract ${ }^{\mathrm{TM} \circledast}$ group (NXS) & 182.8 & $0.897^{\mathrm{b}}$ & $312^{b}$ & 124 & $2.52^{b}$ \\
\hline $\mathrm{Xtract}^{\mathrm{TM}}{ }^{\circledR}$ group (XS) & 189.1 & $1.061^{\mathrm{a}}$ & $395^{\mathrm{a}}$ & 117 & $3.38^{\mathrm{a}}$ \\
\hline SEM & 8.1 & 0.046 & 26 & 15 & 0.23 \\
\hline Probability & NS & $<0.001$ & $<0.01$ & NS & $<0.01$ \\
\hline \multicolumn{6}{|l|}{$\underline{\mathrm{T} * \mathrm{X} \text { Interaction }}$} \\
\hline $\mathrm{NT} * \mathrm{NXS}$ & 185.8 & $0.900^{b}$ & $322^{b}$ & 122 & $2.64^{b}$ \\
\hline NT $* X S$ & 191.9 & $1.063^{\mathrm{a}}$ & $402^{\mathrm{a}}$ & 114 & $3.53^{\mathrm{a}}$ \\
\hline $\mathrm{SNT} * \mathrm{NXS}$ & 179.7 & $0.894^{\mathrm{b}}$ & $301^{\mathrm{b}}$ & 125 & $2.41^{b}$ \\
\hline SNT $*$ XS & 186.2 & $1.059^{\mathrm{a}}$ & $387^{\mathrm{a}}$ & 120 & $3.23^{\mathrm{a}}$ \\
\hline SEM & 7.9 & 0.031 & 21 & 14 & 0.21 \\
\hline Probability & NS & $<0.01$ & $<0.05$ & NS & $<0.01$ \\
\hline
\end{tabular}

${ }_{\mathrm{a}, \mathrm{c}}$ Means, within a column and effect, followed by different superscripts differ significantly.

${ }^{1} \mathrm{SEM}=$ Stander error of the mean.

\section{Ileal mucosa:}

The effects of temperature conditions and feed supplementation with Xtract ${ }^{\mathrm{TM}}$ on the ileal mucosa, of 35-day old male broiler chickens are presented in Table 4. There were no significant effects, due to temperature conditions, on the ileal mucosa morphology. Whereas, birds fed Xtract ${ }^{\mathrm{TM}}$ diet had significantly greater villus height and villus height/crypt depth ratio, as compared to the not treated group. However, no significant differences were found in crypt depth due to the Xtract ${ }^{\mathrm{TM} \circledast}$ supplementation. Significant interaction effects between the two treatments on villus height and villus height/crypt depth ratio were also observed. Within the temperature conditions, birds that consumed the Xtract ${ }^{\mathrm{TM}}{ }^{\circledR}$ diet had significantly higher villus height and villus height/crypt depth ratio, as compared to the no Xtract ${ }^{\mathrm{TM}}$ diet group. Within the
Xtract $^{\mathrm{TM} \circledast}$ treatment, no significant effects due to the temperature conditions were observed on the villus height or villus height/crypt depth ratio.

Relative weights of spleen, thymus and bursa of Fabricius:

There were no significant effects of either temperature conditions or Xtract ${ }^{\mathrm{TM}}{ }^{\circledR}$ supplementation or the interaction between them on the relative weights of spleen, thymus or bursa of Fabricius, for 35-day old male broilers (Table 5).

\section{Humoral Anti-ND vaccine antibody titers:}

Serum antibody responses to vaccination against ND antigen that were determined at 35 days of age are presented in Table 5. Growing birds under SNT conditions resulted in significantly lower antibody titers against ND vaccine. The HI titers against ND vaccine were significantly higher in the Xtract ${ }^{\mathrm{TM}}{ }^{\circ}$ 
group as compared to the no $\mathrm{Xtract}^{\mathrm{TM} \circledast}$ group. There was a significant interaction of the two treatments on the HI titers against ND vaccine. Birds in NT plus Xtract $^{\mathrm{TM} \circledast}$ group had significantly higher HI titers against ND vaccine, as compared to birds in NT plus basal diet and SNT plus basal diet groups. However, the differences between the SNT plus Xtract ${ }^{\mathrm{TM} \circledast}$ and NT plus basal diet groups were not significant.

\section{Profit potential:}

Table (6) summarizes the profit potential of Xtract $^{\mathrm{TM} \otimes}$ supplementation, under normal or subnormal temperature conditions. It was noted that feed supplementation with $\mathrm{Xtract}^{\mathrm{TM}}{ }^{\circledR}$ resulted in significant increase in profit potential, as compared to the not supplemented groups, under normal or subnormal temperature conditions. The profit potential was higher in the $\mathrm{Xtract}^{\mathrm{TM} \otimes}$ fed broilers than the not $\mathrm{Xtract}^{\mathrm{TM}}$ ones by about LE 1.22 and 0.98 per bird, under the normal or subnormal temperature conditions, respectively.

Table 5. Effects of temperature conditions and feed supplementation with $\mathrm{Xtract}^{\mathrm{TM}}{ }^{\circledR}$ on relative weights of lymphoid organs and HI titers against Newcastle disease (ND) vaccine in broilers, at 35 days of age

\begin{tabular}{|c|c|c|c|c|}
\hline \multirow[b]{2}{*}{ Main effects } & \multicolumn{3}{|c|}{ Relative weights of lymphoid organs } & \multirow{2}{*}{$\begin{array}{c}\text { HI titer } \\
\text { against ND } \\
\text { vaccine }\end{array}$} \\
\hline & Spleen & Thymus & $\begin{array}{l}\text { Bursa of } \\
\text { Fabricius }\end{array}$ & \\
\hline \multicolumn{5}{|l|}{ Temperature conditions (T) } \\
\hline$\overline{\text { Normal temperature (NT) }}$ & 0.230 & 0.717 & 0.264 & $6.64^{\mathrm{a}}$ \\
\hline Subnormal temperature (SNT) & 0.288 & 0.714 & 0.261 & $5.71^{\mathrm{b}}$ \\
\hline SEM $^{1}$ & 0.04 & 0.06 & 0.02 & 0.23 \\
\hline Probability & NS & NS & NS & $<0.01$ \\
\hline \multicolumn{5}{|l|}{ Xtract $^{\mathrm{TM} \circledast}{ }^{\circledR}$ supplementation $(\mathrm{X})$} \\
\hline No $\mathrm{Xtract}^{\mathrm{TM} \Theta}$ group (NXS) & 0.226 & 0.709 & 0.265 & $5.56^{\mathrm{b}}$ \\
\hline $\mathrm{Xtract}^{\mathrm{TM} \otimes}$ group (XS) & 0.232 & 0.723 & 0.260 & $6.80^{\mathrm{a}}$ \\
\hline SEM & 0.05 & 0.08 & 0.03 & 0.25 \\
\hline Probability & NS & NS & NS & $<0.01$ \\
\hline \multicolumn{5}{|l|}{$\mathrm{T} * \mathrm{X}$ Interaction } \\
\hline $\mathrm{NT} * \mathrm{NXS}$ & 0.227 & 0.700 & 0.267 & $6.10^{b}$ \\
\hline NT $*$ XS & 0.233 & 0.727 & 0.260 & $7.18^{\mathrm{a}}$ \\
\hline $\mathrm{SNT} * \mathrm{NXS}$ & 0.225 & 0.709 & 0.262 & $5.01^{\mathrm{c}}$ \\
\hline $\mathrm{SNT} * \mathrm{XS}$ & 0.231 & 0.718 & 0.260 & $6.41^{\mathrm{ab}}$ \\
\hline SEM & 0.04 & 0.09 & 0.03 & 0.35 \\
\hline Probability & NS & NS & NS & $<0.01$ \\
\hline
\end{tabular}

Table 6. Effects of feed supplementation with Xtract ${ }^{\mathrm{TM}}$ on profit potential per bird (Egyptian pound), of broilers, under normal or subnormal temperature conditions

\begin{tabular}{|c|c|c|c|c|}
\hline \multirow{2}{*}{$\begin{array}{c}\text { Item } \\
\text { (Egyptian pound/ bird) }\end{array}$} & \multicolumn{2}{|c|}{$\begin{array}{c}\text { Under normal temperature } \\
\text { Conditions }\end{array}$} & \multicolumn{2}{|c|}{$\begin{array}{c}\text { Under subnormal temperature } \\
\text { conditions }\end{array}$} \\
\hline & No Xtract ${ }^{\mathrm{TM} \circledast}$ & $\mathrm{Xtract}^{\mathrm{TM}}{ }^{\circledR}$ & No Xtract ${ }^{\mathrm{TM}}{ }^{\circledR}$ & Xtract $^{\mathrm{TM}}{ }^{\circledR}$ \\
\hline Chick cost ${ }^{1}$ & $3.11 \pm 0.05^{*}$ & $3.09 \pm 0.06$ & $3.16 \pm 0.06$ & $3.14 \pm 0.06$ \\
\hline Feed cost & $14.01 \pm 0.15$ & $14.19 \pm 0.18$ & $14.16 \pm 0.17$ & $14.30 \pm 0.19$ \\
\hline $\mathrm{Xtract}^{\mathrm{TM} \circledast}$ cost & 0.00 & 0.07 & 0.00 & 0.07 \\
\hline $\begin{array}{l}\text { Total cost } \\
\text { Income }\end{array}$ & $\begin{array}{l}17.12 \pm 0.19 \\
26.83 \pm 0.24^{b}\end{array}$ & $\begin{array}{c}17.35 \pm 0.21 \\
28.28 \pm 0.26^{\mathrm{a}}\end{array}$ & $\begin{array}{l}17.32 \pm 0.22 \\
26.01 \pm 0.23^{\mathrm{B}}\end{array}$ & $\begin{array}{r}17.51 \pm 0.25 \\
27.18 \pm 0.22^{\mathrm{A}}\end{array}$ \\
\hline Profit potential & $9.71 \pm 0.12^{\mathrm{b}}$ & $10.93 \pm 0.17^{\mathrm{a}}$ & $8.69 \pm 0.11^{B}$ & $9.67 \pm 0.14^{\mathrm{A}}$ \\
\hline
\end{tabular}

\footnotetext{
${ }^{\mathrm{a}, \mathrm{b}}$ Means, within item, within normal temperature conditions, between $\mathrm{Xtract}^{\mathrm{TM} \circledast}$ treatments, followed $^{\mathrm{T}}$ by different superscripts differ significantly $(P \leq 0.05)$.

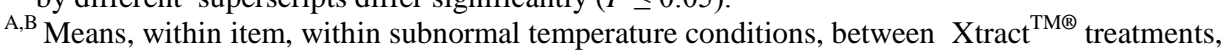
followed by different superscripts differ significantly $(P \leq 0.05)$.

*Means \pm Stander error. $\quad{ }^{1}$ reflects mortality.
}

\section{DISCUSSION}

The present results indicate that rearing broilers under subnormal temperature conditions, from 21 to 35 days of age, had significant negative effects on their production performance parameters and their immune response, as compared to those reared under the recommended normal temperature. These results 
are in agreement with those reported by Olanrewaju et al. (2010), who found that exposure of broiler chicks to temperatures below the thermoneutral zone (18 to $24^{\circ} \mathrm{C}$ ), at 3 weeks of age; adversely affect productive performance, meat yield, immune response, and mortality rate. Furthermore, they stated that, in broilers, even relatively small changes in the temperature conditions from the thermoneutral zone can have a negative effect on their metabolism and performance. Birds subjected to cold conditions had significantly lower carcass yield, poorer feed conversion (Akşit et al., 2013) and higher mortality rate (Ozkan et al., 2010) compared to those reared under recommended normal temperature conditions.

The observed significant reduction in the production performance and immune response, of the broilers, due to the low temperature condition, may be due to an increase in heat production, which increases the oxygen requirement of the body (Ozkan et al. 2010). It was also reported that low oxygen availability might act as a growth-restricting factor and increase the mortality in birds (Daneshyar et al., 2009). It was reported that poor heart performance may be the main cause for bird's death, which leads to significant economic losses under cold conditions (Druyan et al., 2007). Poor heart performance is a major factor in the pathogenesis of hypoxemia in fast-growing broilers (Olkowski, 2007). It is also known that nutrient digestibility decrease when ambient temperature goes below the thermoneutral zone, and the food energy will be directed towards maintenance to sustain normal biological activities rather than towards growth (Sahin and Sahin, 2002).

Prediction of the broiler response to phytogenic compounds supplements is not clear because it is highly influenced by many factors such as the environmental conditions ( Jamroz et al., 2005 and Hashemi and Davoodi, 2010).The current results indicate that feeding Xtract ${ }^{\mathrm{TM}}{ }^{\text {(a mixture containing }}$ $5.4 \%$ carvacrol, $3.2 \%$ cinnamaldehyde, and $2.2 \%$ capsicum oleoresin) to broilers from 1- 35 days of age, had significant improvement effects on production performance, intestinal histomorphological parameters, immune response and a significant profit, under normal and subnormal temperature conditions. Moreover, the Xtract ${ }^{\mathrm{TM} \otimes}$ supplementation alleviated the negative effects of cold stress on production performance and immune response.

The present results are in agreement with those reported by Jamroz et al. (2005) and Bravo et al. (2011). They reported that, the addition of $100 \mathrm{mg} / \mathrm{kg}$ of the Xtract ${ }^{\mathrm{TM} \otimes}$ in the broiler diet increased broiler growth performance and improved the feed conversion ratio. Alali et al. (2013) reported that an essential oil blend (EO; carvacrol, thymol, eucalyptol, lemon) administered in the drinking water of broiler chickens resulted in significant improvements in feed conversion ratio and body weight gain.

On the other hand, our results disagree with those reported by Alp et al. (2012). They found that supplementing diets with oregano essential oil had no significant effects on the carcass yield, or serum IgG level, in broiler chickens at 42 days of age. It was also reported that the essential oil components (carvacrol and cinnamaldehyde) did not affect small intestinal length (Lee et al., 2004b), carcass yield or abdominal fat percentages, but increased weight of jejunum (Tekeli et al., 2006). The differences between these results and our results may be due to the differences in the essential oil components, dose and duration of the supplementation, age of the birds, environmental conditions or the hygienic conditions (Jamroz et al., 2005, Windisch et al., 2008 and Hashemi and Davoodi, 2010).

The positive effects of Xtract ${ }^{\mathrm{TM} \circledast}$ supplementation on the production performance could be related to the improvement of intestinal diameter and villi height that allows larger surface available for nutrient absorption. Potential effects of phytogenic additives on gut morphological characteristics have been reported by Jamroz et al. (2006). Hernandez et al. (2004) demonstrated that Xtract ${ }^{\mathrm{TM} \circledast}$ significantly improved apparent ileal digestibility coefficients for nutrients in broilers diets. Carvacrol and cinnamaldehyde have been shown to increase the activity of the antioxidant enzymes of the cells of the mucosa layer (Dhuley, 1999), which is known to be a protective system for the tissue. The latter could be the basis for the mucosal protective effect previously observed with $\mathrm{Xtract}^{\mathrm{TM} \otimes}$ (Jamroz et al., 2006), who found a thicker layer of mucus on the wall of the glandular jejunum, suggesting a villus-related protective effect of $\mathrm{Xtract}^{\mathrm{TM}}{ }^{\circledR}$. This may explain the positive effects of $\mathrm{Xtract}^{\mathrm{TM}}{ }^{\circledR}$ on the intestinal diameter and ileal mucosa (Mitsch et al., 2004 and Cross et al., 2007) in the present study.

Consequently, dietary factors that improve the morphology of the small intestinal mucosa may improve energy utilization. Bravo et al. (2011) confirmed that the addition of $100 \mathrm{mg} / \mathrm{kg}$ of $\mathrm{Xtract}^{\mathrm{TM} \circledast}$ in the broiler diet increased broiler growth performance and improved energy utilization by, at least, $50 \mathrm{kcal} / \mathrm{kg}$. Thus, a diet containing 2,950 kcal of $\mathrm{ME} / \mathrm{kg}$ plus Xtract ${ }^{\mathrm{TM} \circledast}$ resulted in performance that was equivalent to that of a 3,000 kcal of ME $/ \mathrm{kg}$ diet without Xtract ${ }^{\mathrm{TM} \otimes}$. They explained that the effect of $\mathrm{Xtract}^{\mathrm{TM} \circledast}$ may be mediated through a direct increase in dietary energy digestibility or absorption, by a decrease in the energy required for the maintenance of the digestive tract, or by a combination of both. These observations give further support to the hypothesis that the mixture of these three phytogenics feed additives may stabilize digestive functions and could alleviate the negative effects of cold stress on broilers performance.

The reason for the enhanced digestibility with Xtract ${ }^{\mathrm{TM}}{ }^{\circledR}$ could also be due to increased digestive secretions, as reported for the effect of capsicum oleoresin on pancreatic and intestinal enzyme activity, bile flow and bile acid secretion (Jamroz et al., 2005). Additionally, recent application of highthroughput genomics technology has demonstrated 
that carvacrol, cinnamaldehyde, and capsicum oleoresin are able to alter the expression of 74, 62, and 254 genes involved in metabolism (Kim et al., 2010).

Furthermore, the observed positive effects of Xtract ${ }^{\mathrm{TM}}{ }^{\circ}$ on the production performance and immune response can be attributed to the essential oils present in this mixture (carvacrol, cinnamaldehyde, and capsicum oleoresin) and its active constituents which possess antibacterial, antifungal and antioxidant activities due to the presence of phenolic compounds (Lee et al., 2004a, Kollanoor-Johny et al., 2012 and Renata et al., 2012). Carvacrol has been shown to inhibit Salmonella growth (Burt et al., 2007) and Escherichia .coli (Renata et al., 2012), in chickens. Cinnamaldehyde has been proven to have strong antibacterial activity against Escherichia coli, Pseudomonas aeruginosa, Staphylococcus aureus and Salmonella sp. (Chang et al., 2001).

Furthermore, Kollanoor-Johny et al. (2012) reported that Carvacrol and Cinnamaldehyde exhibit a wide range of antimicrobial activity and act synergistically when combined. They suggested that a blend of essential components may be more effective in improving growth performance than an identical amount of an individual component alone. Also, capsicum oleoresin contains anti-bacterial activity (Loizzo et al., 2008). Moreover, Renata et al. (2012) showed that mixture of carvacrol, cinnamaldehyde, and capsicum oleoresin administration caused a reduction in Eimeria sp. oocysts. Therefore, the lower mortality rate in $\mathrm{Xtract}^{\mathrm{TM} \otimes}$ group may also be attributed to the growth promotion action against pathogenic microorganisms that can attack young chicks.

In addition, Lillehoj et al. (2010) reported that analysis of global gene expression profiles of intestinal tissues from phytgenics-fed birds indicated that capsicum oleoresin induced the most gene changes compared to the control group, where many of these genes were associated with those of immunity. The most reliable network induced by dietary cinnamaldehyde treatment was related to the functions of antigen presentation, humoral immune response, and inflammatory disease. They stated that the phytogenics carvacrol, cinnamaldehyde, and capsicum oleoresin have shown beneficial effects on host immune system through the regulation of gene expression in the chicken gut. These may explain the evidence of positive effects of $\mathrm{Xtract}^{\mathrm{TM} \Theta}$ on the immune response and mortality rate in the present study.

In summary, the results of the present study indicate that, the mixture containing phytogenics; carvacrol, cinnamaldehyde, and capsicum oleoresin (Xtract ${ }^{\mathrm{TM}}$ ) could be used as economical growth promoter in broilers, via feed, under normal and subnormal temperature conditions. Additionally, it could alleviate the negative effects of cold stress on broilers production performance and enhance their immune response.

\section{CONCLUSIONS}

In conclusion, a commercial mixture $\left(\right.$ Xtract $^{\mathrm{TM}}{ }^{\circledR}$ ) containing three phytogenics (carvacrol, cinnamaldehyde, and capsicum oleoresin) was proved to increase final body weight, improve final feed conversion ratio, decrease total mortality percentage, enhance HI titers against ND vaccine and increase profit potential, in broilers. These results provide clear evidence to support the idea that the phytoogenics; carvacrol, cinnamaldehyde, and capsicum oleoresin could be used as economical feed additive growth promoter in broilers, up to 35 days of age. Moreover, Xtract ${ }^{\mathrm{TM} \otimes}$ supplementation may alleviate the negative effects of cold stress on broilers production performance and immune response.

Further research on the effect of these phytoogenics on broilers performance and immune response under other stressful conditions should be done. With respect to consumer safety, further research is still needed to study the effects of this mixture on the broilers meat quality.

\section{REFERENCES}

Alali, W. Q., C. L. Hofacre, G. F. Mathis and G. Faltys, 2013. Effect of essential oil compound on shedding and colonization of Salmonella enterica serovar Heidelberg in broilers. Poultry Science, 92: 836-841.

Alp, M., M. Midilli, N. Kocabağlı, H. Yılmaz, N. Turan, A. Gargilı and N. Acar, 2012. The effects of dietary oregano essential oil on live performance, carcass yield, serum immunoglobulin $\mathrm{G}$ level, and oocyst count in broilers. Journal of Applied Poultry Research, 21: 630-636

Akşit, M., S. Yalçın, P. B. Siegel, Ç. Yenisey, D. Özdemir and S. Özkan, 2013. Broilers respond to cooler ambient temperatures after temperature acclimation during incubation and early postnatal age. Journal of Applied Poultry Research, 22: 298-307.

Bravo, D., P. Utterback , and C. M. Parsons, 2011. Evaluation of a mixture of carvacrol, cinnamaldehyde, and capsicum oleoresin for improving growth performance and metabolizable energy in broiler chicks fed corn and soybean meal. Journal of Applied Poultry Research, 20:115-120

Burt, S. A., 2004. Essential oils: their antibacterial properties and potential applications in foods $-\mathrm{a}$ review. International Journal of Food Microbiology, 94: 223-253.

Burt, S. A, M. Fledderman, H. Haagsman, F. Van Knapen and E. Veldhuizen, 2007. Inhibition of Salmonella enterica serotype enteritidis on agar and raw chicken by carvacrol vapour. International Journal of Food Microbiology, 97:346-350.

Burt, S. A., R. Vlielander, H. Haagsman and E. Veldhuizen, 2005. Increase in activity of essential 
oil components carvacrol and thymol against Escherichia coli O157:H7 by addition of food stabilizers. Journal of Food Protection, 68: 919-926.

Chang, S.T, P Chen and S.C Chang, 2001. Antibacterial activity of leaf essential oils and their constituents from Cinnamomum osmophloeum. Journal of Ethnopharmacology, 77:123-127.

Cross, D. E., R. M. McDevitt, K. Hillman, and T. Acamovic, 2007. The effect of herbs and their associated essential oils on performance, dietary digestibility and gut microflora in chickens from 7 to 28 days of age. British Poultry Science, 48:496-506.

Daneshyar, M., H. Kermanshahi and A. Golian, 2009. Changes of biochemical parameters and enzyme activities in broiler chickens with coldinduced ascites. Poultry Science, 88:106-110.

De Vincenzi, M., A. Stammati, A. Vincenzi and M. Silano, 2004. Constituents of aromatic plants: carvacrol. Fitoterapia, 75:801-804.

Dhuley, J. N., 1999. Anti-oxidant effects of cinnamon (Cinnamomum verum) bark and greater cardamon (Amomum subulatum) seeds in rats fed a high fat diet. Indian Journal of Experimental Biology, 37:238-242.

Druyan, S., A. Ben-David and A. Cahaner, 2007. Development of ascites-resistant and ascitessusceptible broiler lines. Poultry Science, 86:811822.

Duncan, D.B., 1955. Multiple range and multiple F testes. Biometrics, 11:7-42.

Elmenawey, M.A. and H. B. Gharib, 2013. Effects of monospecies and multispecies probiotics on productive performance, intestinal histomorphological parameters and immune response in broilers. Egyptian Journal of Animal Production, 50:93-102.

Hashemi, S.R. and H. Davoodi, 2010. Phytogenics as new class of feed additive in poultry industry. Journal of Animal and Veterinary Advances, 9: 2295-2304.

Hernandez, f., J. Madrid, V. Garcia, J. Orengo and M.D. Megias, 2004. Influence of two plant extracts on broiler performance, digestibility, and digestive organ size. Poultry Science, 83:169174.

Jamroz, D., A.Wiliczkiewicz, T. Wertelecki, J. Orda and J. Skorupinska, 2005. Use of active substances of plant origin in chicken diets based on maize and locally grown cereals. British Poultry Science, 46:485-493.

Jamroz, D., T. Wertelecki, M. Houszka, and C. Kamel, 2006. Influence of diet type on the inclusion of plant origin active substances on morphological and histochemical characteristics of the stomach and jejunum walls in chickens. Journal of Animal Physiology and Animal Nutrition, 90:255-268.

Karimi , A., F. Yan , C. Coto , J. H. Park , Y. Min , C. Lu , J. A. Gidden, J.O. Lay and P.W. Waldroup, 2010. Effects of level and source of oregano leaf in starter diets for broiler chicks. Journal of Applied Poultry Research, 19:137-145.

Kim, D. K., H. S. Lillehoj, S. H. Lee, S. I. Jang and D. Bravo, 2010. High-throughput gene expression analysis of intestinal intraepithelial lymphocytes after oral feeding of carvacrol, cinnamaldehyde, or Capsicum oleoresin. Poultry Science, 89:68-81

Kollanoor-Johny, A., A. Upadhyay, S. A. Baskaran, I. Upadhyaya, S. Mooyottu, N. Mishra, M. J. Darre, M. I. Khan, A. M. Donoghue, D. J. Donoghue and K. Venkitanarayanan, 2012. Effect of therapeutic supplementation of the plant compounds transcinnamaldehyde and eugenol on Salmonella enterica serovar Enteritidis colonization in market-age broiler. Journal of Applied Poultry Research, 21: 816-822

Lee, J., K. Chang, and G. Kim, 2009. Composition and anti-inflammatory activities of Zanthoxylum schinifolium essential oil: suppression of inducible nitric oxide syntheses, cyclooxygenase2, cytokines and cellular adhesion. Journal of the Science of Food and Agriculture, 89:1762-1769.

Lee, K.W., H. Everts and A.C. Beynen, 2004a. Essential oils in broiler nutrition. International Journal of Poultry Science, 3: 738-752.

Lee, K.W., H. Everts, H. J. Kappert and A.C. Beynen, 2004b. Growth performance of broiler chickens fed a carboxymethyl cellulose containing diet with supplemental carvacrol and/or cinnamaldehyde. International Journal of Poultry Science, 3: 619-622.

Lee, K.W., H. Everts, H. Kappert, K. H. Yeom and A.C. Beynen, 2003. Dietary carvacrol lowers body weight gain but improves feed conversion in female broiler chickens. Journal of Applied Poultry Research, 12:394-399.

Lee, S., H. Lillehoj, S. Jang, E. Lillehoj, W. Min and D. Bravo, 2013. Dietary supplementation of young broiler chickens with Capsicum and turmeric oleoresins increases resistance to necrotic enteritis. British Journal of Nutrition, 9: $1-8$.

Lillehoj, H. S., D. K. Kim, D. M. Bravo and S. H. Lee, 2010. Effects of dietary plant-derived phytonutrients on the genome-wide profiles and coccidiosis resistance in the broiler chickens. Inter. Symposium on Animal Genomics for Animal Health. Paris, France. 31 May - 2 June 2010.

Loizzo M.R, R. Tundis, F. Menichini and G.A. Statti, 2008. Influence of ripening stage on health benefits properties of Capsicum annuum var. acuminatum L.: in vitro studies. Journal of Medicinal Food, 11:184-189.

Mitsch, P., K. Zitterl-Eglseer, B. Kohler, C. Gabler, R. Losa, and I. Zimpernik, 2004. The effect of two different blends of essential oil components on the proliferation of Clostridium perfringens in the intestines of broiler chickens. Poultry Science, 83:669-675. 
NRC, 1994. Nutrient Requirements of Poultry, 9th ed., (Washington, DC, National Academy press).

Olanrewaju, H. A., J. L. Purswell, S. D. Collier and S. L. Branton, 2010. Effect of ambient temperature and light intensity on physiological reactions of heavy broiler chickens. Poultry Science, 89:2668-2677.

Olkowski, A. A., 2007. Pathophysiology of heart failure in broiler chickens: Structural, biochemical, and molecular characteristics. Poultry Science, 86:999-1005.

Ozkan, S., C. Takma, S. Yahav, B. Soğut, L. Turkmut, H. Erturun and A. Cahaner, 2010. The effects of feed restriction and ambient temperature on growth and ascites mortality of broilers reared at high altitude. Poultry Science, 89:974-985.

Puvaca, N., V. Stanacev, D. Glamocic, J., Levic, L. Peric, V. Stanacev and D. Milic, 2013. Beneficial effects of phytoadditives in broiler nutrition. World's Poultry Science Journal, 69: 27-34.

Renata S., A. Lauková, L. Chrastinová, V. Strompfová, M. P. Simonová, I. Plachá, Z. Vasilková, M. Chrenková and S. Faix, 2012. Benefficial effect of plant extracts in rabbit husbandry. Acta Veterinaria Brno, 81: 245-250.

Sahin, K. and N. Sahin, 2002. Effects of chromium picolinate and ascorbic acid dietary supplementation on nitrogen and mineral excretion of laying hens reared in a low ambient temperature $\left(7^{\circ} \mathrm{C}\right)$. Acta Veterinaria Brno, 71 : 183-189.

Samanya, M. and K. Yamauchi, 2002. Histological alterations of intestinal villi in chickens fed dried Bacillus subtilis. Comparative Biochemistry and Physiology, 133:95-104.
SAS, 1999. User's Guide, Release 8th ed. (Cary, NC, SAS Institute).

Stanacev, V., D. Glamocic, N. Milosevic, N. Puvaca, V. Stanacev and N. Plavsa, 2011. Effect of garlic (Allium sativum L.) in fatting chick's nutrition. African Journal of Agricultural Research, 6: 943948.

Swayne, D.E., J.R. Glisson, M.W. Jackwood, J.E. Pearson and W.M. Reed, 1998. A laboratory manual for the isolation and identification of avian pathogens. 4th Ed, American Association Of Avian Pathologists. Inc., Kennett Square, Pennsylvania, USA.

Tekeli, A., L. Celik, H.R. Kutlu and M. Gorgulu, 2006. Effect of dietary supplemental plant extracts on performance, carcass characteristics, digestive system development, intestinal microflora and some blood parameters of broiler chicks. XII, EPC, Verona, Italy, 10 - 14 September, 2006.

Timmerman, H., A. Veldman, E. van den Elsen, F. Rombouts and A. Beynen, 2006. Mortality and growth performance of broilers given drinking water supplemented with chicken-specific probiotics. Poultry Science, 85:1383-1388.

Windisch, W., K., Schedle, C. Plitzner and A. Kroismaryr, 2008. Use of phytogenic products as feed additives for swine and poultry. Journal of Animal Sciences, 86: 140-148.

Zhang, A. W., B. D. Lee, S. K. Lee, K. W. Lee, G. H. An, K. B. Song, and C. H. Lee, 2005. Effects of yeast (saccharomyces cerevisiae) cell components on growth performance, meat quality, and ileal mucosa development of broiler chicks. Poultry Science, 84:1015-1021.

\section{تقييم استخدام مركبات الفيتوجينك على العليقة كمنشط للنمو لكتاكيت انتاج اللحم المرباه تحت ظروف درجات الحرارة العادية أو المنخفضمة

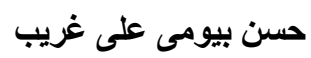

قسم الإنتاج الحيو/نس، كلية النزراعة، جامعة القاهرة

تم إجر اء هذه الدر اسة لتقييم إضافة خلبط يثتمل على ثلاثة من مركبات الفيتوجينك (كرفكرول - سيناملدهيد - مستخلص الفلفل الحار) تحت

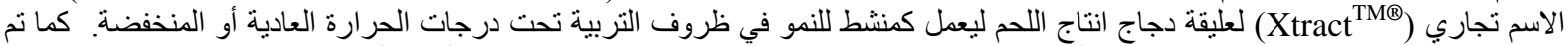

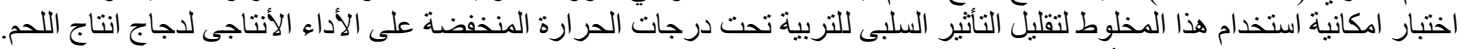

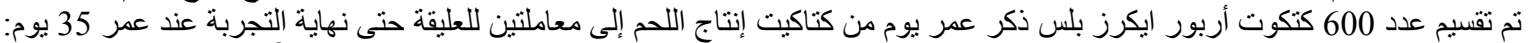

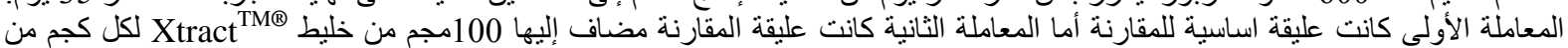

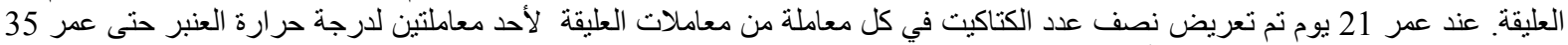

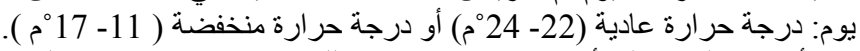

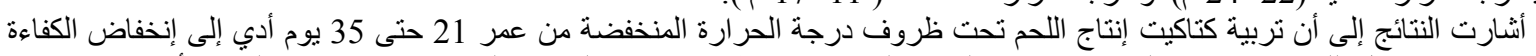

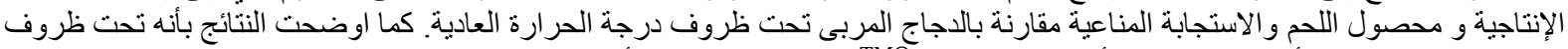

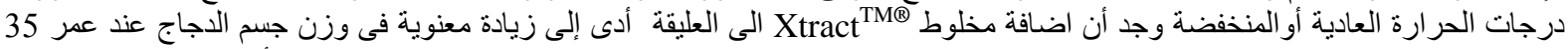

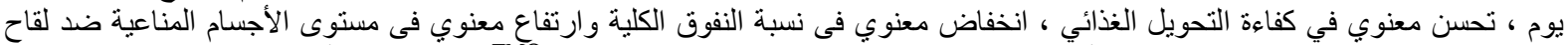

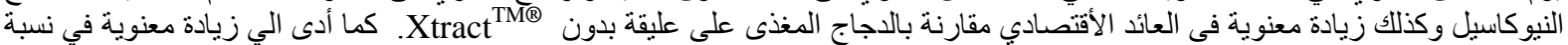

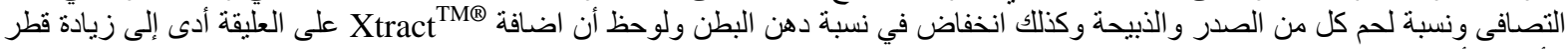

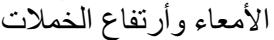

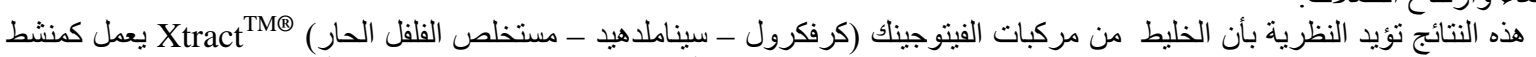

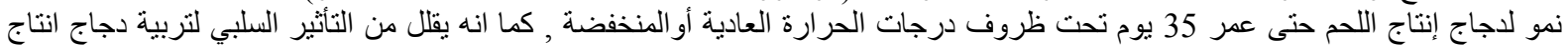

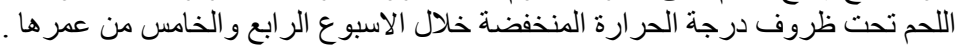

